\title{
Effect Trigonella foenumgraecum and Tinospora cordifolia feed additives on Carcass Traits of Broilers in Konkan Climatic Conditions of India
}

\author{
V.Y. Bharambe ${ }^{1 *}$ and Y.A. Garde ${ }^{2}$ \\ ${ }^{1}$ Department of Animal Husbandry and Dairy Science, College of Agriculture, Dapoli, Dist-Ratnagiri, Maharashtra, INDIA \\ ${ }^{2}$ Department of Agricultural Statistics, N.M. College of Agriculture, Navsari Agricultural University, Navsari, Gujarat, INDIA
}

"Corresponding author: VY Bharambe; E-mail: vikas.agri@rediffmail.com

Received: 11 Sept., 2020

Revised: 02 Nov., 2020

Accepted: 15 Nov., 2020

\begin{abstract}
The different types of feed and combination of feeds are the major element in growth and getting high net return from the poultry. Feed additive plays important role in improving the efficiency of feed utilization and animal performance. The current study attempted to determine the influence of herbs i.e. fenugreek (Trigonella foenumgraecum), guduchi (Tinospora cordifolia) and in combinations of both at different levels in diet of broilers. The experimental trial was conducted with one hundred sixty two unsexed day-old Vencobb-400 broilers chicks. The nine treatments were given with three replication and each replicates had six birds. The herb stem powder were fed for six weeks at $0,0.1$ and 0.2 per cent level of each herb in combinations. In order to evaluate the seasonal variation it was conducted throughout the year viz. summer, rainy and winter. The chicks were fed with maize crumble at 0-4 days then starter feed from 5-21 days and 21-42 days with finisher feed. All the birds were managed under uniform managemental conditions in three seasons of Konkan climatic conditions. The experimental results showed that the significant increased dressed weight, dressing per cent, giblet, breast, drumstick thigh and meat to bone ratio in broiler fed with 0.2 per cent fenugreek seed and guduchi stem powder during winter season than rest of the treatments and seasons. It would be suggested that the supplementation of broiler chicks' diets with 0.2 per cent fenugreek seed and guduchi stem powder improved the carcass characteristics of broilers.
\end{abstract}

\section{HIGHLIGHTS}

(0 Carcass traits were improved due to supplementation of 0.2 per cent fenugreek seed and guduchi stem powder.

( D Dressing percentage was better in winter than other season due supplementation of herb powder.

Keywords: Broilers, fenugreek seed and guduchi stem, herb powder, and carcass traits

Poultry is the term that is used to refer to birds raised for profit. The white-feathered chickens bred specifically for meat production are called broilers, fryers roasters, depending on the size they will be raised too. The modern poultry industry emerged in the late twenty one century in Europe and America as breeders focused on improving meat and egg production (FAO, 2010). Feed is a major component, affecting net return from the poultry business, because 80 per cent of the total expenditure in terms of cash is spent on feed purchase (Khan et al., 2010). Feed costs in poultry farms are the largest production component which reached up to 70 percent. The Broilers need high quality feed to sustain growth. Giving feed additive is proven to improve feed efficiency so that it provides profits for farmers (Utami and Wahyono, 2018). Many research strategies have been practiced such as introducing feed supplements and feed additives to ensure more net return and minimize high expenditure on feed (Khan et al., 2009). In the past the major growth promoters were antibiotics. Antibiotic compounds are commonly included in poultry diets for promoting of growth and control of diseases.

How to cite this article: Bharambe, V.Y. and Garde, Y.A. (2020). Effect Trigonella foenumgraecum and Tinospora cordifolia feed additives on carcass traits of broilers in Konkan climatic conditions of India. J. Anim. Res., 10(6): 953-959.

Source of Support: None; Conflict of Interest: None

(क) 
The problems arise when broilers are given high quality feed and feed use additionally antibiotics. According to the study of (Barton, 2000) antibiotic resistance causes problems in animals and public health. Plant extracts are alternative to antibiotic and anticoccidials and need to do sufficient research studies for effective use of it. The current research is looking for natural alternative to antibiotics because of their residue and subsequent resistance to bacteria. At present the scientists are working to improve feed efficiency and growth rate of livestock using useful herbs (Khan et al., 2010).

Feed additive are important materials that can improve the efficiency of feed utilization and animal performance. The possibility of using new natural alternative additives instead of antibiotics and hormone in animal diets is being recently used. Some plants, containing various essential oils, have been used as alternative remedies by some researchers (Ceylan et al., 2003). Some studies have indicated that various plants extracts can improve feed conversion ratio, increase carcass quality, decrease the market age of broiler and reduced their rearing cost (Javed et al., 2009).

Fenugreek (Trigonella foenum-graecum L.) is a well known medicinal plant that grows in nature and mainly cultivated in India, Pakistan and China. Fenugreek seeds have many therapeutic effects like hypoglycemic, anthelmintic, antibacterial, anti-inflammatory, antipyretic, and antimicrobial properties (Bash et al., 2003). It contains neurin, biotin, trimethylamine which tends to stimulate the appetite by their action on the nervous system (Al Habori and Roman, 2002).

Another herb, Guduchi (Tinospora cordifolia) belongs to a group of medicinal plants that grow in the tropical and subtropical regions of India (Sengupta et al., 2011). It is also well known for its immunomodulatory, antioxidant, antibacterial and antiviral properties (Srinivasan et al., 2008). Tinospora, also known as Giloy, is a member of the family Menispermaceae in the genus Tinospora. Tinospora is a native plant from India. It is well known Indian bitter and prescribed in fever, diabetes, dyspepsia, jaundice, urinary problems, skin diseases and chronic diarrhea and dysentery. Tinospora has also been indicated useful in the treatment of heart diseases, leprosy, helmenthiasis and rheumatoid arthritis (Kirtikaret al., 1933, Shah and Nighantu, 1969). In view of this, the present investigation was carried out to study the influence of combinations of fenugreek and guduchi powder on carcass traits of broilers under climatic conditions of Konkan region, India.

\section{MATERIALS AND METHODS}

A total one hundred sixty two Vencobb-400 broiler chicks day-old age belonging to the same hatch and uniform body sized were randomly assigned to nine dietary treatments. Each treatment consists of three replications and each repetition consist of six chicks. The experimental details are shown in Table 1.

Table 1: Feeding and treatment regimen of broilers during experiment

\begin{tabular}{|c|c|c|c|c|}
\hline $\begin{array}{l}\text { Treatment } \\
\text { groups }\end{array}$ & Particulars & $\begin{array}{c}\text { Number of } \\
\text { replicates }\end{array}$ & $\begin{array}{l}\text { Number } \\
\text { of birds/ } \\
\text { replicate }\end{array}$ & Total \\
\hline $\mathrm{T}_{0}$ & Control- Basal diet & 3 & 6 & 18 \\
\hline $\mathrm{T}_{1}$ & $\begin{array}{l}\text { Control + } 0.1 \% \text { FSP } \\
\text { of basal diet }\end{array}$ & 3 & 6 & 18 \\
\hline $\mathrm{T}_{2}$ & $\begin{array}{l}\text { Control }+0.2 \% \text { FSP } \\
\text { of basal diet }\end{array}$ & 3 & 6 & 18 \\
\hline $\mathrm{T}_{3}$ & $\begin{array}{l}\text { Control }+0.1 \% \text { GSP } \\
\text { of basal diet }\end{array}$ & 3 & 6 & 18 \\
\hline $\mathrm{T}_{4}$ & $\begin{array}{l}\text { Control }+0.2 \% \text { GSP } \\
\text { of basal diet }\end{array}$ & 3 & 6 & 18 \\
\hline $\mathrm{T}_{5}$ & $\begin{array}{l}\text { Control }+0.1 \% \text { FSP } \\
+0.1 \% \text { GSP of basal } \\
\text { diet }\end{array}$ & 3 & 6 & 18 \\
\hline $\mathrm{T}_{6}$ & $\begin{array}{l}\text { Control }+0.1 \% \text { FSP } \\
+0.2 \% \text { GSP of basal } \\
\text { diet }\end{array}$ & 3 & 6 & 18 \\
\hline $\mathrm{T}_{7}$ & $\begin{array}{l}\text { Control }+0.2 \% \text { FSP } \\
+0.1 \% \text { GSP of basal } \\
\text { diet }\end{array}$ & 3 & 6 & 18 \\
\hline $\mathrm{T}_{8}$ & $\begin{array}{l}\text { Control }+0.2 \% \text { FSP } \\
+0.2 \% \text { GSP of basal } \\
\text { diet }\end{array}$ & 3 & 6 & 18 \\
\hline Total & & & & 162 \\
\hline
\end{tabular}

*FSP $=$ Fenugreek Seed Powder, GSP = Guduchi Stem Powder.

The broilers chicks were vaccinated with Lassota strain and Gumboro on the end of first week and end of third week. The birds were fed as per Bureau of Indian Standards (B.I.S.) specifications (1992) to meet the energy and protein requirements during first phase with 
maize crumbles (0-4 days), starters phase (5-21 days) and finisher phase (21-42 days). All the birds in treatment groups were offered ad libitum drinking water and feed throughout the experimental period of six weeks under uniform managemental conditions. At $42^{\text {nd }}$ days of age, two broiler birds from each replicate was randomly selected, individually weighed and slaughtered, feather plucked manually then washed and drained, eviscerated individual organs (liver, heart, gizzard, wings, breast, thigh, abdominal fat, back, and intestine) were separately weighed and it was expressed in per cent of live weight.

Data were analyzed based on a randomized block design model (Snedocor and Cochran, 1994) using the SPSS software. Means were considered as significantly different at $\mathrm{P}<0.05$ level of the significance and further subjected to least significance difference $(l s d)$ test.

\section{RESULTS AND DISCUSSION}

The data concerning the carcass characteristics of broiler birds fed with different dietary experimental treatments are presented in Table 2. The results showed that broiler chicks fed with diets containing 0.2 per cent fenugreek seed and guduchi stem powder recorded significantly $(\mathrm{P}<0.05)$ improved carcass characteristics in broiler reared under winter season of Konkan region than the rest of the dietary treatments and seasons. The average dressed weight of broiler birds was significantly $(\mathrm{P}<0.05)$ higher in winter season than other season. However, the gizzard and heart percentage was significantly $(\mathrm{P}<0.05)$ more in rainy season than other seasons. The average giblet percentage did not differ significantly $(\mathrm{P}>0.05)$ between different seasons. However, higher giblet percentage was observed in rainy season $(4.83 \%)$ in experimental broiler birds followed by winter $(4.77 \%)$ and summer season $(4.73 \%)$. It was observed that dietary inclusion of FSP and GSP alone at different levels and its combinations significantly affected the dressed weight, dressing percentage, liver, heart, and gizzard percentage in different seasons. The present study is in concomitance with those reported by (Panda, 1991, ElHusseiny et al., 2002) who reported that there was notable improvement in overall carcass yield and carcass quality parameters on dietary addition of herbal liver tonics (Liv52) containing geloi and fenugreek seeds. The dressed weight ranged from 1073.20 to $1476.16 \mathrm{~g}$ among the dietary treatments. The dressed weight linearly increased level of inclusions of FSP and GSP and its combinations and the differences between treatments were significant $(\mathrm{P}<0.05)$. The results were agreed with the findings of (Alsultan, 2003 and Durrani et al., 2006).

The supplementation of geloi powder of different level significantly $(\mathrm{P}<0.05)$ increased liver and heart percentage this might be due to efficacy of liver and heart protected organs from damage. It was observed that both the photogenic feed additive FSP and GSP showed hepatoprotective property during the experimental period in broilers.

The interaction effect of season vs treatments was found non significant $(\mathrm{P}>0.05)$ between broiler birds. There was no significant effect $(\mathrm{P}>0.05)$ season vs treatment for dressed weight, dressing percentage, gizzard and giblet percentage of experimental birds. However, interaction effect was found significant $(\mathrm{P}<0.05)$ for liver and heart percentage of broiler chickens at the end of experiment. It was revealed from the present findings inclusion of FSP and GSP alone and its combinations showed significantly improved the carcass quality of experimental broiler chicks in different seasons. The data analysis showed that significant $(\mathrm{P}<0.05)$ decreased abdominal fat percentage $(2.24 \%)$ intestine percentage $(5.80 \%)$ and wings percentage $(8.04 \%)$ in summer season than other seasons. It was observed that significant increased $(\mathrm{P}<0.05)$ in breast percentage $(26.32 \%)$, drumstick $(13.15 \%)$ and thigh percentage $(13.75 \%)$ in winter season followed by rainy season and summer season. Kalanter et al. (2007) reported that the broiler birds fed with thyme and licorice significantly decreased the abdominal fat percentage and increased breast weight in broilers. Toaha et al. (2016) reported that weights of thigh, drumstick and breast was increased and decreased wings, intestine and abdominal fat percentage in broilers fed with different level of fenugreek seeds.

The per cent weight of abdominal fat, breast, drumstick, thigh, wings and intestine ranged from 1.98 to $3.23,23.13$ to $27.56,10.73$ to $12.82,11.45$ to $13.42,8.32$ to 11.90 and 6.02 to 6.56 , respectively (Table 2). The percent weight of breast, drumstick and thigh increased linearly with increased level of inclusion of FSP and GSP and its combinations from 0.1 to 0.2 per cent in the diet. However, significantly lowest $(\mathrm{P}<0.05)$ abdominal fat per cent was observed in $\mathrm{T}_{8}(1.98 \%)$ than other dietary 
Table 2: Influence of combinations of fenugreek and guduchi powder on carcass traits of broilers in Konkan climatic conditions

\begin{tabular}{|c|c|c|c|c|c|c|c|c|c|c|c|c|}
\hline \multirow[b]{2}{*}{ Treatments } & \multirow[b]{2}{*}{$\begin{array}{l}\text { Final Body } \\
\text { Weight (g) }\end{array}$} & \multirow[b]{2}{*}{$\begin{array}{l}\text { Dressed } \\
\text { weight.(g) }\end{array}$} & \multirow[b]{2}{*}{$\begin{array}{l}\text { Dressing } \\
\text { per cent }\end{array}$} & \multicolumn{9}{|c|}{ Per cent live weight } \\
\hline & & & & $\begin{array}{l}\text { Liver } \\
(\%)\end{array}$ & $\begin{array}{l}\text { Gizzard } \\
(\%)\end{array}$ & $\begin{array}{l}\text { Heart } \\
(\%)\end{array}$ & $\begin{array}{l}\text { Giblet } \\
(\%)\end{array}$ & $\begin{array}{l}\text { Abdominal } \\
\text { fat }(\%)\end{array}$ & $\begin{array}{l}\text { Breast } \\
(\%)\end{array}$ & $\begin{array}{l}\text { Drumstick } \\
(\%)\end{array}$ & $\begin{array}{l}\text { Thigh } \\
(\%)\end{array}$ & $\begin{array}{l}\text { Wings } \\
(\%)\end{array}$ \\
\hline \multicolumn{13}{|l|}{ Seasons } \\
\hline $\mathrm{S}_{1}$ (Summer) & $1858.86^{\mathrm{b}}$ & $1304.74^{b}$ & $70.09^{b}$ & $2.25^{\mathrm{a}}$ & $1.85^{\mathrm{b}}$ & $0.66^{\mathrm{b}}$ & $4.73^{\mathrm{b}}$ & $2.24^{\mathrm{b}}$ & $23.37^{\mathrm{c}}$ & $11.07^{\mathrm{b}}$ & $11.70^{\mathrm{b}}$ & $8.04^{\mathrm{c}}$ \\
\hline $\mathrm{S}_{2}$ (Rainy) & $1720.22^{c}$ & $1213.27^{\mathrm{c}}$ & $70.44^{\mathrm{b}}$ & $2.19^{\mathrm{b}}$ & $1.96^{\mathrm{a}}$ & $0.69^{\mathrm{a}}$ & $4.83^{\mathrm{a}}$ & $2.41^{\mathrm{a}}$ & $25.03^{\mathrm{b}}$ & $10.86^{\mathrm{b}}$ & $11.54^{\mathrm{b}}$ & $10.75^{\mathrm{a}}$ \\
\hline $\mathrm{S}_{3}$ (Winter) & $1939.43^{\mathrm{a}}$ & $1406.11^{\mathrm{a}}$ & $72.91^{\mathrm{a}}$ & $2.26^{\mathrm{a}}$ & $1.90^{\mathrm{ab}}$ & $0.63^{\mathrm{c}}$ & $4.77^{\mathrm{ab}}$ & $2.28^{\mathrm{b}}$ & $26.32^{\mathrm{a}}$ & $13.15^{\mathrm{a}}$ & $13.75^{\mathrm{a}}$ & $9.70^{\mathrm{b}}$ \\
\hline $\mathrm{SEM} \pm$ & 11.00 & 12.69 & 0.77 & 0.02 & 0.02 & 0.01 & 0.04 & 0.03 & 0.18 & 0.08 & 0.08 & 0.06 \\
\hline $\mathrm{CD}(\mathrm{P}<0.05)$ & 31.21 & 36.02 & 2.19 & 0.06 & 0.06 & 0.02 & NS & 0.07 & 0.50 & 0.22 & 0.22 & 0.18 \\
\hline \multicolumn{13}{|l|}{ Treatments } \\
\hline$\overline{\mathrm{T}_{0} \text { (Control) }}$ & $1630.88^{\mathrm{f}}$ & $1073.20^{\mathrm{d}}$ & $65.85^{\mathrm{e}}$ & $2.11^{\mathrm{c}}$ & $1.74^{\mathrm{d}}$ & $0.64^{\text {cde }}$ & $4.49^{\mathrm{c}}$ & $3.23^{\mathrm{a}}$ & $23.13^{\mathrm{d}}$ & $10.73^{\mathrm{d}}$ & $11.45^{\mathrm{d}}$ & $11.90^{\mathrm{a}}$ \\
\hline $\mathrm{T}_{1}$ & $1835.06^{\text {cde }}$ & $1291.54^{\mathrm{c}}$ & $70.54^{\text {bcd }}$ & $2.20^{\mathrm{c}}$ & $1.88^{\mathrm{bc}}$ & $0.69^{\mathrm{ab}}$ & $4.79^{b}$ & $2.58^{\mathrm{b}}$ & $24.07^{\mathrm{c}}$ & $11.23^{\mathrm{c}}$ & $11.87^{\mathrm{c}}$ & $9.80^{\mathrm{b}}$ \\
\hline $\mathrm{T}_{2}$ & $1885.26^{\mathrm{abc}}$ & $1377.45^{\mathrm{b}}$ & $73.08^{\mathrm{abc}}$ & $2.34^{\mathrm{b}}$ & $1.91^{\mathrm{bc}}$ & $0.66^{\mathrm{c}}$ & $4.90^{\mathrm{b}}$ & $2.04^{\mathrm{ef}}$ & $26.00^{\mathrm{b}}$ & $12.45^{\mathrm{ab}}$ & $13.07^{\mathrm{ab}}$ & $9.05^{\mathrm{d}}$ \\
\hline $\mathrm{T}_{3}$ & $1829.06^{\text {de }}$ & $1294.83^{c}$ & $70.87^{\mathrm{bcd}}$ & $2.18^{\mathrm{c}}$ & $1.91^{\mathrm{bc}}$ & $0.68 b^{c}$ & $4.76^{\mathrm{b}}$ & $2.36^{\mathrm{c}}$ & $24.02^{c}$ & $11.31^{\mathrm{c}}$ & $11.95^{\mathrm{c}}$ & $9.53^{\mathrm{bc}}$ \\
\hline $\mathrm{T}_{4}$ & $1808.98 \mathrm{e}$ & $1248.21^{\mathrm{c}}$ & $68.95^{\mathrm{de}}$ & $2.14^{\mathrm{c}}$ & $1.91^{\mathrm{bc}}$ & $0.72^{\mathrm{a}}$ & $4.78^{\mathrm{b}}$ & $2.21^{\mathrm{d}}$ & $24.25^{\mathrm{c}}$ & $11.42^{\mathrm{c}}$ & $12.07^{\mathrm{c}}$ & $9.75^{\mathrm{b}}$ \\
\hline $\mathrm{T}_{5}$ & $1872.93^{\mathrm{bcd}}$ & $1310.11^{\mathrm{c}}$ & $69.89^{\mathrm{cd}}$ & $2.10^{\mathrm{c}}$ & $1.84^{\mathrm{cd}}$ & $0.65^{\mathrm{cd}}$ & $4.56^{\mathrm{b}}$ & $2.15^{\mathrm{de}}$ & $24.44^{\mathrm{c}}$ & $11.37^{\mathrm{c}}$ & $11.99^{\mathrm{c}}$ & $9.38^{\mathrm{c}}$ \\
\hline $\mathrm{T}_{6}$ & $1850.14 c^{\mathrm{de}}$ & $1304.44^{c}$ & $71.05^{\mathrm{bcd}}$ & $2.19^{\mathrm{c}}$ & $1.97^{\mathrm{ab}}$ & $0.66^{\mathrm{bc}}$ & $4.82^{\mathrm{c}}$ & $2.17^{\mathrm{d}}$ & $24.69^{c}$ & $11.58^{c}$ & $12.21^{\mathrm{c}}$ & $9.06^{\mathrm{d}}$ \\
\hline $\mathrm{T}_{7}^{0}$ & $1904.59^{\mathrm{ab}}$ & $1398.41^{\mathrm{a}}$ & $74.07^{\mathrm{ab}}$ & $2.35^{\mathrm{b}}$ & $1.93^{b c}$ & $0.61^{\mathrm{e}}$ & $4.80^{\mathrm{b}}$ & $2.09^{d}$ & $26.00^{\mathrm{b}}$ & $12.32^{\mathrm{b}}$ & $12.93^{\mathrm{c}}$ & $8.68^{\mathrm{e}}$ \\
\hline $\mathrm{T}_{8}$ & $1938.62^{\mathrm{a}}$ & $1474.16^{\mathrm{a}}$ & $76.05^{\mathrm{a}}$ & $2.49^{\mathrm{a}}$ & $2.06^{\mathrm{a}}$ & $0.61^{\mathrm{de}}$ & $5.09^{\mathrm{a}}$ & $1.98^{\mathrm{def}}$ & $27.56^{\mathrm{a}}$ & $12.82^{\mathrm{a}}$ & $13.42^{\mathrm{a}}$ & $8.32^{\mathrm{f}}$ \\
\hline$\underline{\mathrm{SEM} \pm}$ & 19.05 & 21.98 & 1.34 & 0.04 & 0.04 & 0.01 & 0.06 & 0.05 & 0.31 & 0.13 & 0.13 & 0.11 \\
\hline $\mathrm{CD}(\mathrm{P}<0.05)$ & 54.06 & 62.38 & 3.79 & 0.10 & 0.11 & 0.04 & 0.17 & 0.13 & 0.87 & 0.38 & 0.38 & 0.30 \\
\hline \multicolumn{13}{|l|}{ Interaction } \\
\hline $\mathrm{SEM} \pm$ & 33.00 & 38.08 & 2.32 & 0.06 & 0.07 & 0.02 & 0.11 & 0.08 & 0.53 & 0.23 & 0.23 & 0.19 \\
\hline $\mathrm{CD}(\mathrm{P}<0.05)$ & NS & NS & NS & 0.17 & NS & 0.06 & NS & NS & 1.51 & 0.66 & 0.66 & 0.53 \\
\hline
\end{tabular}

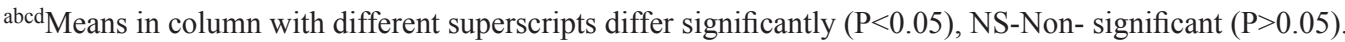

treatments and control (3.23\%). It was observed from the data the significantly $(\mathrm{P}<0.05)$ higher breast percentage in $\mathrm{T}_{8}(27.56 \%)$ followed by $\mathrm{T}_{2}(26.00 \%), \mathrm{T}_{7}(26.00 \%)$, $\mathrm{T}_{6}(24.69 \%), \mathrm{T}_{5}(24.44 \%), \mathrm{T}_{4}(24.25 \%), \mathrm{T}_{1}(24.07 \%), \mathrm{T}_{3}$ $(24.02 \%)$ and $\mathrm{T}_{0}(23.13 \%)$. These findings are agreement with the findings of (Alloui et al., 2012; Duru et al., 2013; Shewita and Taha, 2011 and Muhammad et al., 2009). It was observed that abdominal fat in abdominal area of broilers is regarded as waste in the poultry industry, since it represent loss in the market and reduced consumer acceptability. The results of the current study indicated that FSP and GSP supplementation of broiler diets has the potential to reduce this type waste (abdominal fat). In accordance with current results, Panda, (1991) and Aksa et al. (2002) who reported addition of Liv-52 (Tinospora cordifolia) and fenugreek seeds, respectively. The decrease in abdominal fat might be due to diosgenin, trigoneline and levamisole in FSP and GSP which has the potential to suppress or inhibited preadipocyte differentiation through the down regulation of lipogenesis in the liver (Weerasingha and Atapattu, 2013). The same study also reported that diosgenin (fenugreek) supplementation inhibit hepatic fatty acid synthesis activity and increased beta oxidation of fatty acids (Mamoun, 2014). These findings are agreement with the findings of Shraddha et al. (2017) who reported that orano-morphometric study showed that the birds of group $\mathrm{T}_{3}$ and $\mathrm{T}_{5}$ had significantly higher weights of both digestive and digestive organs as compared to all other groups. They concluded that APE and TCE significantly improved the dressed weight and carcass traits of broiler birds.

The increasing of breast percentage may be due to optimum antioxidant activity of fenugreek and geloi (diosgenin, trigonelline, gitogenin, levamisole, biotin and neurin) Khan et al., 2009 and Panda, 1991) that stimulates protein synthesis by broiler bird enzymatic system. Fenugreek seed powder supplementation could increase the amount of lean meat ratio and reduce the risk of hyperlipidemia in the consumers (Elbushra, 2012).

There was a significant difference $(\mathrm{P}<0.05)$ in drumstick and thigh per cent among the treatment groups (Table 2). 
Inclusion of FSP and GSP and its combinations treatments $\left(\mathrm{T}_{8}\right)$ has the upper most drumstick and thigh percentage 12.82 and 13.42 per cent, compare to all dietary treatments groups and control group birds (10.73\% and $11.45 \%)$. Supplementation of phytogenic feed additives was significant promoted drumstick and thigh yield $(\mathrm{P}<0.05)$ than control group. It was observed that increasing trend in drumstick and thigh percentage with increasing level of FSP and GSP in broiler diets. The data revealed that significantly highest drumstick percentage was found in $\mathrm{T}_{8}(12.82 \%)$ at par with $\mathrm{T}_{2}(12.45 \%)$. The pertaining from Table 2 proved that significantly highest $(\mathrm{P}<0.05)$ thigh yield was observed in $\mathrm{T}_{8}(13.42 \%)$ than other dietary treatments and control. Duru et al. (2013) who reported significant increased in drumstick and thigh percentage in broiler birds fed with fenugreek seed powder as additives. These results are in agreement with earlier studies. Marcincak et al. (2011) who indicated that higher drumstick and thigh muscles of poultry fed with cloves in feed stuff and agrimony extract in water as phytogenic feed additives. They also found that plumb less importance of plant feeding additives is also in terms of quality of produced meat. Most of the plants and their extract have strong antioxidant properties, significantly resulting in lower fat oxidation during storage of meat.

The treatment differences affected significantly $(\mathrm{P}<0.05)$ on wings and intestine percentage of experimental broiler birds. The broiler chicken in group $\mathrm{T}_{8}(8.32 \%$ wings and $6.10 \%$ intestine) was significantly $(\mathrm{P}<0.05)$ lowest than other dietary treatments and control group. It was observed that significant $(\mathrm{P}<0.05)$ lowest percentage of wings in $\mathrm{T}_{4}(9.75 \%)$ which was at par with $\mathrm{T}_{2}(9.80 \%)$ and $\mathrm{T}_{3}(9.53 \%)$. It was observed from statistical data the results showed that significant $(\mathrm{P}<0.05)$ lowest percentage of intestine in $\mathrm{T}_{2}(6.02 \%)$ which was at par with $\mathrm{T}_{1}(6.25$ $\%), \mathrm{T}_{3}(6.23 \%), \mathrm{T}_{4}(6.22 \%), \mathrm{T}_{5}(6.10 \%), \mathrm{T}_{7}(6.06 \%)$ and $\mathrm{T}_{8}(6.10 \%)$, respectively. However, treatment $\mathrm{T}_{2}$ showed that significant $(\mathrm{P}<0.05)$ intestine per cent was lowest than control of FSP and GSP and its combinations significantly $(\mathrm{P}<0.05)$ reduced the wings and intestine percent in experimental broiler birds.

These findings agreed with Alloui et al. (2012) and Weerasingha and Atapattu, (2013) who reported that significant lowest percent of wings and intestine in broiler birds supplemented with fenugreek. Rabia, (2010) who reported that fenugreek, parsley and basil seeds $(3 \mathrm{~g} / \mathrm{kg}$ feed) affected on intestine weight and its percentage in broiler birds.

The data showed that there was no significant $(\mathrm{P}>0.05)$ effect of season vs treatments for abdominal fat percentage in experimental broiler birds. It was proved that there was effect of dietary treatments was independent. The lowest value $(\mathrm{P}<0.05)$ of abdominal fat per cent was observed in $\mathrm{S}_{3} \mathrm{~T}_{8}(1.90 \%)$ than other interaction effects. It was observed from the data analysis showed lowest abdominal fat percent in broiler birds supplemented with 0.2 per cent FSP and GSP in winter season than other dietary treatments and seasons. The per cent weight of breast, drumstick, thigh, wings and intestine was significantly differ $(\mathrm{P}<0.05)$ among the interactions. It was observed from the statistical data showed significantly $(\mathrm{P}<0.05)$ highest percentage of breast, drumstick and thigh in winter season was 28.58, 14.32 and 14.89 in broiler birds fed with 0.2 per cent of FSP and GSP, respectively. It was proved from these findings dietary inclusion of FSP and GSP combination at 0.2 per cent level significantly $(\mathrm{P}<0.05)$ increased the breast, drumstick and thigh in winter season.

The per cent of back and legs was significantly $(\mathrm{P}<0.05)$ higher in rainy season 14.24 and 3.89 than other seasons (Table 3). It was observed from the data there was significant $(\mathrm{P}<0.05)$ effect of season on back and legs percentage of broiler birds. Results proved that dietary inclusion of FSP and GSP and their combinations at different levels $(0.1$ and $0.2 \%)$ significantly $(\mathrm{P}<0.05)$ affected the back and legs percentages in experimental broiler birds among the seasons.

The meat to bone ratio ranged from 2.57 to 3.35 among different seasons. The meat to bone ratio was significantly higher $(\mathrm{P}<0.05)$ in broilers birds reared under winter season with different dietary treatments of FSP and GSP and its combinations (Table 3). However, significantly $(\mathrm{P}<0.05)$ higher meat to bone ratio was in winter season (3.35) followed by summer (2.90) and rainy season (2.57). The average back and legs percentage ranged from 11.99 to 14.66 and 3.19 to 3.84 among the different treatments. It was observed that significantly $(\mathrm{P}<0.05)$ lowest back percentage was found in treatment $\mathrm{T}_{8}(11.99 \%)$ than other dietary treatments and control. Results also showed that significant $(\mathrm{P}<0.05)$ lower value of legs was found in treatment $\mathrm{T}_{8}(3.19 \%)$ than other treatments groups. However, treatment $\mathrm{T}_{8}$ was at par with $\mathrm{T}_{7}(3.34 \%)$ 
Table 3: Influence of combinations of fenugreek and guduchi powder on carcass traits of broilers in Konkan climatic conditions

\begin{tabular}{|c|c|c|c|c|}
\hline \multirow{2}{*}{ Treatments } & \multicolumn{3}{|c|}{ Per cent live weight } & \multirow{2}{*}{ Meat : Bone ratio } \\
\hline & Back (\%) & Legs (\%) & Intestine (\%) & \\
\hline \multicolumn{5}{|l|}{ Seasons } \\
\hline $\mathrm{S}_{1}$ (Summer) & $13.28^{\mathrm{b}}$ & $2.97^{\mathrm{c}}$ & $5.80^{\mathrm{c}}$ & $2.90^{\mathrm{b}}$ \\
\hline $\mathrm{S}_{2}$ (Rainy) & $14.24^{\mathrm{a}}$ & $3.89^{\mathrm{a}}$ & $6.51^{\mathrm{a}}$ & $2.57^{\mathrm{c}}$ \\
\hline $\mathrm{S}_{3}$ (Winter) & $12.61^{\mathrm{c}}$ & $3.57^{\mathrm{b}}$ & $6.32^{\mathrm{b}}$ & $3.35^{\mathrm{a}}$ \\
\hline $\mathrm{SEM} \pm$ & 0.13 & 0.03 & 0.05 & 0.04 \\
\hline $\mathrm{CD}(\mathrm{P}<0.05)$ & 0.37 & 0.09 & 0.14 & 0.11 \\
\hline \multicolumn{5}{|l|}{ Treatments } \\
\hline $\mathrm{T}_{0}$ (Control) & $14.66^{\mathrm{a}}$ & $3.84^{\mathrm{a}}$ & $6.56^{\mathrm{a}}$ & $2.57^{\mathrm{d}}$ \\
\hline $\mathrm{T}_{1}$ & $13.42^{\mathrm{bcd}}$ & $3.43^{b c}$ & $6.25^{\mathrm{bc}}$ & $2.87^{\mathrm{c}}$ \\
\hline $\mathrm{T}_{2}$ & $12.98^{\mathrm{de}}$ & $3.56^{\mathrm{b}}$ & $6.02^{\mathrm{c}}$ & $3.16^{\mathrm{b}}$ \\
\hline $\mathrm{T}_{3}^{2}$ & $13.78^{\mathrm{bc}}$ & $3.47^{\mathrm{bc}}$ & $6.23^{\mathrm{bc}}$ & $2.81^{\mathrm{c}}$ \\
\hline $\mathrm{T}_{4}^{3}$ & $13.19^{\text {cd }}$ & $3.44^{\mathrm{bc}}$ & $6.22^{\mathrm{bc}}$ & $2.78^{\mathrm{c}}$ \\
\hline $\mathrm{T}_{5}^{4}$ & $13.90^{\mathrm{b}}$ & $3.44^{\mathrm{bc}}$ & $6.10^{\mathrm{bc}}$ & $2.82^{\mathrm{c}}$ \\
\hline $\mathrm{T}_{6}$ & $13.98^{\mathrm{b}}$ & $3.57^{\mathrm{b}}$ & $6.33^{\mathrm{ab}}$ & $2.81^{\mathrm{c}}$ \\
\hline $\mathrm{T}_{7}^{6}$ & $12.48 \mathrm{e}^{\mathrm{f}}$ & $3.34^{\mathrm{cd}}$ & $6.06^{\mathrm{c}}$ & $3.24^{\mathrm{ab}}$ \\
\hline $\mathrm{T}_{8}$ & $11.99^{\mathrm{f}}$ & $3.19^{\mathrm{d}}$ & $6.10^{\mathrm{bc}}$ & $3.42^{\mathrm{a}}$ \\
\hline $\mathrm{SEM} \pm$ & 0.23 & 0.05 & 0.09 & 0.07 \\
\hline $\mathrm{CD}(\mathrm{P}<0.05)$ & 0.64 & 0.16 & 0.25 & 0.19 \\
\hline \multicolumn{5}{|l|}{ Interaction } \\
\hline$\overline{\mathrm{SEM}} \pm$ & 0.39 & 0.09 & 0.15 & 0.12 \\
\hline $\mathrm{CD}(\mathrm{P}<0.05)$ & NS & 0.27 & 0.43 & 0.33 \\
\hline
\end{tabular}

abcdMeans in column with different superscripts differ significantly $(\mathrm{P}<0.05)$, NS-Non- significant $(\mathrm{P}>0.05)$.

for percent legs yield of experimental broiler birds. It was observed that inclusion of FSP and GSP at 0.2 percent levels in broiler diet improved the back and legs percentages in experimental broiler birds. Those results agreed with findings of Panda, (1991) who reported that addition Liv-52 (Tinospora cordifolia constituents) in broiler diet had effects on carcass traits. Moreover, Alloui et al. (2012) found that addition of fenugreek seeds in broiler diet significantly decreased the back and legs yield of broilers than those fed control diets. Findings of the study agreed with the findings of Mamoun et al. (2014) who indicated that there was in improvement in carcass traits with feeding of fenugreek seeds at 2.0 and 3.0 per cent level in broilers.

The meat to bone ratio ranged from 2.57 to 3.42 among different dietary treatments. The meat to bone ratio (3.42) was significantly higher $(\mathrm{P}<0.05)$ in broilers birds fed diets containing FSP and GSP at 0.2 per cent level compared to other treatments (Table 3$)$. However, treatment $T_{2}(0.2 \%$ FSP) showed 2.87 meat to bone ratio which was at par with $\mathrm{T}_{3}, \mathrm{~T}_{4}, \mathrm{~T}_{5}, \mathrm{~T}_{6}$. Results showed that significantly lowest meat to bone ratio was found in $\mathrm{T}_{0}(2.57)$ than other dietary treatment. The increased meat to bone ratio observed in experimental broiler birds may be attributed to positive effect of FSP and GSP and its combinations in the diet than control. These results were in agreement with report of Aksa et al. (2002).

There was no significant effect $(\mathrm{P}>0.05)$ was observed in season vs treatments in back percentage. The results showed that there was significant $(\mathrm{P}<0.05)$ difference between season vs treatment for legs yield and meat to bone ratio of experimental broiler birds. Results showed that higher meat to bone ratio was observed in $\mathrm{S}_{3} \mathrm{~T}_{8}$ (3.98) than other interactions. The results indicated that dietary inclusion of FSP and GSP at 0.2 per cent level in broiler diet improved meat to bone ratio during winter season than other dietary treatments and seasons. It was also found that addition of FSP and GSP at 0.2 per cent level may be used to improve the meat to bone ratio in broiler chickens. 


\section{REFERENCES}

Aksa, S., Ben, S.N., Alloui, O. and Lombarkiu, F. 2002. Fenugreek seed (Trigonellafoenum-graecum) an alternative to antibiotic growth promoters for broiler. J. Agric., 41(2): $57-63$.

Alloui, N.B., Aksa, M., Alloui, N. and Ibrir, F. 2012. Utilization of fenugreek (Trigonellafoenum-graecum) as growth promoter for broiler chickens. J. Worlds. Poult. Res., 2(2): 25-27.

Al-Sultan, S.I. 2003. The effect of Curcuma longa (turmeric) on overall performance of broiler chickens. Int. J. Poult. Sci., 2(5): 351-353.

Barton, M.D. 2000. Antibiotic use in animal feed and its impact on human health. Nutr. Res. Rev., 13(2): 279-299.

Bash, E., Ulbricht, C., Kuo, G., Szapary, P. and Smith, M. 2003. Therapeutic applications of fenugreek. Altern Med. Rev., 8 : 20-27.

Ceylan, N., Ciftci, I. and Ilhan, Z. 2003. The effect of some alternative feed additive for antibiotic growth promoters on the performance and gut microflora of broiler chicks. Turkey J. Vet. Anim. Sci., 27: 727-733.

Durranni, F.R., Ismall, M., Sultan, A., Suhail, S.M., Chand, M. and Durranni, Z. 2006. Effect of different levels of feed added turmeric on growth performance of broiler chicks. $J$. Agric. Biol. Sci., 1: 9-11.

Duru, M., Zeynep, E. Asuman Duru, A., Alpaslan Kaya, D. and Şahin, A. 2013. Effect of seed powder of herbal legume fenugreek (Trigonella foenum-graceum L.) on growth performance, body components, digestive parts, and blood parameters of broiler chicks. Pakistan J. Zool., 45(4): 10071014.

El-Husseiny, O., Shalash, S.M. and Azouz, H.M. 2002. Response of broiler performance to diets containing hot pepper and/ or fenugreek at different metabolizable energy levels. Egypt Poult. Sci., 22: 387-406.

Khan, F.U., Durrani, F.R., Sultan, A., Khan, R.U. and Naz, S. 2009. Effect of fenugreek (Trigonella foenumgraecum) seed extract on visceral organs of broiler chicks. J. Agri. Bio. Sci., 4: 58-61.

Khan, F.V., Ulla, A., Rahman, B.U., Naz, B. and Nadir, N. 2009. Fenugreek (Trigonellafoenum-graecum $\mathrm{L}$ ) effect on muscles growth of broiler chicks. J. Poult. Sci., 1(1):1-3.
Khan, R.U., Durrani, F.R., Chand, N. and Anwar, H. 2010. Influence of feed supplementation with Cannabis sativa on quality of broilers carcass. Pakistan Vet. J., 30: 34-38.

Kirtikar, K.R. and Basu, B.D. 1933. Indian Medicinal Plants,. Conf. Allahabad, India, 1: 77.

Marcincak, S., Popelka, P., Zdolec, N., Martonova, M., Simcova, J. and Marcincakova, D. 2011. Effect of supplementation of phytogenic feed additives on performance parameters and meat quality of broiler chickens. Slov. Vet. Res., 48(1): 27-34.

Panda, B.K. 1991. Effect of Livol treatment on experimentally induced aflatoxicosis in broilers. Indian J. Indg. Med., 8: 5154.

Rabia, J.A. 2010. Effect of using fenugreek, parsley and sweet basil seeds as feed additives on the performance of broiler chickens. Int. J. Poult. Sci., 9(3): 278-282.

SAS. 2010. Statistical Analysis software Version 9.3, SAS Institute Inc. Cary, North Carolina, USA.

Sengupta, M., Sharma, G.D. and Chakraborty, B. 2011. Effect of aqueous extract of Tinospora cordifolia on functions of peritoneal macrophages isolated from $\mathrm{CC}_{14}$ intoxicated male albino mice. BMC J. Altern. Complement Med., 11(1): 102 10.

Shah, B. and Nighantu, K. 1969. Adarsh Vol. 1, (Hindi translation), (Chowkhambha Vidya Bhavan,Varanasi), pp. 680 .

Srinivasan, G.V., Unnikrishnan, K.P., Shree, A.B. and Balachandran, I. 2008. HPLC estimation of berberine in Tinospora cordifolia and Tinospora sinensis. Indian $J$. Pharm. Sci., 70(1): 96-99.

Tuncer, H.I. 2007. To banned usage of hormones, antibiotics, anticoccidials and drugs in compound animal feed. Journal of Lalahan Anim. Res. Inst., 47(13): 29-37.

Utami, M.M.D. and Wahyono, N.D. 2018. Supplementation of probiotic and prebiotic on the performance of broilers IOP Conf. Ser., Earth Environ. Sci., 207: 01202.4

Weerasingha, A.S. and Atapattu, N.S.B.M. 2013. Effects of fenugreek (Trigonella foenum-graecum L) seed powder on growth performance, haematalogy, nitrogen relation of broiler chicken. Tropical Agric. Res., 24(3): 289-295. 
